\title{
Wage Inequality between Men and Women in Côte D'Ivoire: An Oaxaca-Blinder Decomposition Method
}

\author{
Kouadjo San Boris Bediakon1, Kacou Firmin Croi², Kouadio Baudouin Koko, \\ Aké Alex Declerc Boua ${ }^{1}$ \\ ${ }^{1}$ Faculty of Economics and Management, Jean Lorougnon GUEDE University of Daloa, Côte d'Ivoire \\ ${ }^{2}$ Faculty of Economics Development, University Alassane OUATTARA of Bouake, Côte d'Ivoire \\ Email: sanboris1@gmail.com, kcroi@yahoo.fr, kokobaudouin2010@gmail.com,delsonake@gmail.com
}

How to cite this paper: Bediakon, K. S. B., Croi, K. F., Koko, K. B., \& Boua, A. A. D. (2022). Wage Inequality between Men and Women in Côte D'Ivoire: An Oaxaca-Blinder Decomposition Method. Theoretical Economics Letters, 12, 52-75.

https://doi.org/10.4236/tel.2022.121004

Received: December 21, 2021

Accepted: January 18, 2022

Published: January 21, 2022

Copyright $\odot 2022$ by author(s) and Scientific Research Publishing Inc. This work is licensed under the Creative Commons Attribution International License (CC BY 4.0).

http://creativecommons.org/licenses/by/4.0/

\begin{abstract}
The purpose of this study is to analyze the wage gap between men and women in Côte d'Ivoire. More specifically, it aims to assess the main aspects of gender inequality in the functioning of the labor market in Côte d'Ivoire. The factors underlying the wage gap between men and women are examined empirically using the Oaxaca-Blinder decomposition method. The data used are from the 2016 National Survey on the Situation of Employment and the Informal Sector (ENSESI) among households. The results of the study show that, more $74.16 \%$ of the total wage gap remains unexplained by objective factors. In addition, wage inequality varies by socio-demographic characteristics (age, gender, education), employment setting (urban or rural), and by sector and employment status. Finally, the total wage gap is predominantly explained by age, work experience, socio-professional category (senior manager) and form of remuneration.
\end{abstract}

\section{Keywords}

Wage Gap between Men and Women, Wage Inequality between Men and Women, Oaxaca-Blinder Decomposition, Explained Gap, Unexplained Gap

\section{Introduction}

Gender wage inequality remains a widespread problem around the world and has been the subject of numerous studies. It has become one of the most debated topics in the economic literature and its issues are still relevant today. According to Wolfelsperger, the concept of wage discrimination refers to unfavorable treat- 
ment of a group with certain identical characteristics, regardless of their productive characteristics (Hammouda \& Souag, 2011). Most often, these characteristics relate to: age, gender, level of education, sector of employment, professional experience, etc. In most countries of the world, there is no country where women's wages are equal to men's (Meulders, Plasman, \& Rycx, 2005). Thus, studies have shown that women suffer from wage inequality in both developed and developing countries. Authors such as Ponthieux \& Meurs (2004), have shown in their report that in the European Union countries in 2000, women's wages represented between $80 \%$ and $95 \%$ of men's wages in hourly terms, and $65 \%$ and $80 \%$ in monthly terms. The work of Coudin, Maillard, \& Tô (2017) on hourly wages by gender in the private sector, shows that women earn $14.3 \%$ less per hour than men.

For this reason, the topic of gender wage gaps is increasingly attracting the attention of the scientific world. For developing countries, employment is an important issue for policy makers. Unemployment rates, the strong growth of low-productivity and low-paying precarious jobs, the explosion of the informal sector, and gender issues are the most visible features of the labor market in developing countries. Furthermore, empirical studies in some African countries have shown that there are significant wage gaps between men and women. For example, the study on Cameroon found that the average wage gap against women is around $52.36 \%$ (Ekamena, 2014). In Côte d'Ivoire, the economic situation and demographic strength have led to destruction and imbalance in the labor market. According to the General Housing and Population Census (2014), the Ivorian population is estimated at $22,671,331$ inhabitants, with $51.6 \%$ men versus $48.4 \%$ women. Also, the socio-political crisis that has shaken the country in recent years has weakened its economic system in general and more particularly that based on the labor market. Employment in Côte d'Ivoire is almost dominated by the informal sector (93.9\%) where $91.9 \%$ of men and $96.8 \%$ of women are employed. The latter are also predominantly present in sectors of activity such as trade (31.7\%) and services (23.7\%). On the other hand, they are poorly represented in formal jobs (3.2\%) (ENSESI, 2016).

However, the mechanisms that govern these inequalities in the job market in Côte d'Ivoire are not always easy to understand. On the conceptual level, socio-economic factors, cultural factors and gender have been used to explain these inequalities. On the theoretical and empirical level, multiple studies have been undertaken to explain and measure the wage gap between men and women. Thus, it is still of interest to understand why wage inequalities exist between men and women in many countries. The objective of this article is to explain and characterize the wage differentials between men and women in the labor market in Côte d'Ivoire. Using the method developed by Oaxaca and Blinder (1973), we will study the explanatory factors of these inequalities.

To do this, the work will be structured in three sections. The first describes an analysis of the labor market in Côte d'Ivoire. The second concerns theoretical 
and empirical literature on wage inequality. The third section is reserved for the methodological approach of the Oaxaca-Blinder decomposition and the different results.

\subsection{Analysis of the Labor Market in Côte D'Ivoire}

As Table 1 indicates and as in most of sub-Saharan Africa, the labor market in Côte d'Ivoire is dominated by the informal sector (93.9\%), which is mainly found in agricultural activity. This informal sector plays an important and growing role in the absorption of the active population. As for agriculture, it contributes $22 \%$ of GDP and is the source of income for two-thirds of the country's households (BAD, 2015). Women and men play different and often complementary roles in ensuring the country's economic and social development. The predominance of informal employment remains marked among both men and women even though, among employed women, very few have a formal job (3.2\%) compared to $8.1 \%$ for men. In addition, there is a multitude of workers and entrepreneurs in Côte d'Ivoire who work in the informal economy, and also in precarious conditions. However, these workers are poor, unregistered, and lack insurance (Lognon, 2013). Gender discrimination at work also exists in this sector. For example, according to the INS survey (2008), the level of capital is very low among women in the informal sector compared to men. $94.6 \%$ of the shares they manage have a capital of less than 452 USD.

Several factors deserve special attention in monitoring the labor market in Côte d'Ivoire. These are the labor force in the labor market, gender disparities in economic activity, and the wage structure.

\subsection{The Labor Force in the Côte D'Ivoire Labor Market}

According to the ENSESI report (2016), the working age population in Côte d'Ivoire is $14,870,704$ out of a total projected population of $23,681,171$, or 62.8 percent (see Table 2). This population is made up of $50.5 \%$ men and $49.5 \%$ women. The Ivorian labor force represents $58.2 \%$ of the total population of working age. The employed and unemployed populations are estimated at about $97.2 \%$ and $2.8 \%$ of the workforce, respectively. The gender breakdown of the employed population shows that the proportion of men $(67.2 \%)$ is higher than

Table 1. Distribution of employment by type (in \%) by gender.

\begin{tabular}{cccc}
\hline Socio-demographic characteristics & Formal job & Informal job & Total \\
\hline$\underline{\text { Sex }}$ & 8.1 & 91.9 & 100 \\
Men & 3.2 & 96.8 & 100 \\
Women & 6.1 & 93.9 & 100 \\
Combined &
\end{tabular}

Note: The percentage distribution of employment by type and gender according to data from the national survey on the employment situation and the informal sector in 2016. 
Table 2. Structure of the workforce (in \%) by individual characteristics.

\begin{tabular}{cccc}
\hline $\begin{array}{c}\text { Characteristics } \\
\text { of people }\end{array}$ & $\begin{array}{c}\text { Working-age } \\
\text { population }\end{array}$ & $\begin{array}{c}\text { Employed } \\
\text { population }\end{array}$ & $\begin{array}{c}\text { Unemployed } \\
\text { population }\end{array}$ \\
\hline Men & 50.5 & $\underline{\text { Sex }}$ & \\
Women & 49.5 & 67.2 & 2.3 \\
Education level & 3.5 \\
No education & 47.1 & 61.2 & 1.4 \\
Primary & 22.4 & 60.3 & 2.2 \\
Secondary & 25.4 & 44.1 & 5.2 \\
Tertiary & 3.5 & 55.5 & 11.7 \\
Combined & 62.8 & 97.2 & 2.8 \\
\hline
\end{tabular}

Note: The characteristics of individuals and the structure of the labor force according to the survey on the situation of employment and the informal sector in 2016.

that of women (45.8\%). Moreover, the employment rate varies with the level of education. Indeed, it is higher among individuals with no education (61.2\%) and those with primary education $(60.3 \%)$ and is relatively low with higher education (55.5\%). Unemployment, which is low overall, tends to increase with the level of education. Indeed, in 2016, the unemployment rate was $2.8 \%$ and $11.7 \%$ of working-age individuals with the higher level were unemployed, compared to $1.4 \%$ for individuals with no education. It is also generally noted that women are more vulnerable to unemployment than men, (3.5\% versus $2.3 \%$ ).

The increasingly competitive labor market requires a good level of training and skills. However, women face many barriers to employment in most African countries because of their limited training.

Gender-related behaviors and practices in the labor market in Côte d'Ivoire are rooted in the traditional patriarchal system, which is unfavorable to the promotion of women's activities. The precarious and informal nature of women's work is mainly explained by the principles of separation and hierarchy in society. Thus, the man is considered the head of the family and must therefore work to meet the family's needs, while the role of the woman is essentially domestic. Consequently, it is easy to understand why, despite the existence of employment opportunities, women are excluded or reduced to precarious or marginal jobs. Also, the norms that govern the relationship between men and women vary from one region of the country to another.

\subsection{Gender Disparities in Economic Activity}

In recent years, the labor force participation rate in Côte d'Ivoire has increased from 55.7 percent in 2013 to 58.2 percent in 2016 according to the new employment statistics standards. This rate varies greatly depending on the gender of the 
population. The behavior of women in the Ivorian labor market has declined and remains low, but has not reached that of men. Their labor force participation rate fell from $49.2 \%$ in 2013 to $47.4 \%$ in 2016 . However, that of men increased from $61.8 \%$ to $68.8 \%$. Thus, the labor force participation gap between men and women increased from 12.6 percentage points in 2013 to 21.4 percentage points in 2016, an increase of 10 percentage points. The unemployment rate in Côte d'Ivoire decreased significantly from 5.3 percent in 2013 to 2.8 percent in 2016. It was higher among women (3.5\%) than men (2.3\%) in 2016. However, the unemployment gap between men and women in the labor market decreased by 1 percentage point between 2013 and 2016 (Table 3).

\subsection{Wage Structure}

Gender wage differentials also depend on the wage structure of the country in question. According to Becker's (1964) human capital theory, men and women have different endowments in terms of education and experience, thus occupying jobs in different sectors. According to the World Bank (2015), the average income in Côte d'Ivoire is low, even compared to comparable countries in Sub-Saharan Africa. Based on 2013 macroeconomic data, the average monthly income of a worker in Côte d'Ivoire is estimated to be about 175 USD, an amount below the average for Sub-Saharan Africa.

However, according to the results of ENSESI (2016), the average monthly wage of employees is estimated at 159 USD, a difference of 16 USD compared to that estimated by the World Bank in 2015. However, this salary is not homogeneous regardless of sociodemographic characteristics (area of residence, gender, age group, and level of education). Men have a relatively better average monthly salary (169 USD) than women (124 USD), with a gap of about 45 USD (ENSESI, 2016) as shown in Figure 1.

\section{Review of the Literature on Wage Inequality}

\subsection{Theoretical Framework on Wage Inequality}

In the economic literature, several studies have analyzed the reasons for wage

Table 3. Distribution of labor force and unemployment (\%) by gender.

\begin{tabular}{ccccc}
\hline \multirow{2}{*}{ Characteristics } & \multicolumn{2}{c}{2013} & \multicolumn{2}{c}{2016} \\
\cline { 2 - 5 } & Workforce & Unemployment & Workforce & Unemployment \\
\hline Sex & & & & \\
Men (M) & 61.8 & 4.3 & 68.8 & 2.3 \\
Women (W) & 49.2 & 6.6 & 47.4 & 3.5 \\
Combined & 55.7 & 5.3 & 58.2 & 2.8 \\
Ecart de genre (H-F) & 12.6 & -2.3 & 21.4 & -1.2 \\
\hline
\end{tabular}

Source: ENSETE (2013), ENSESI 2016, by Authors. 


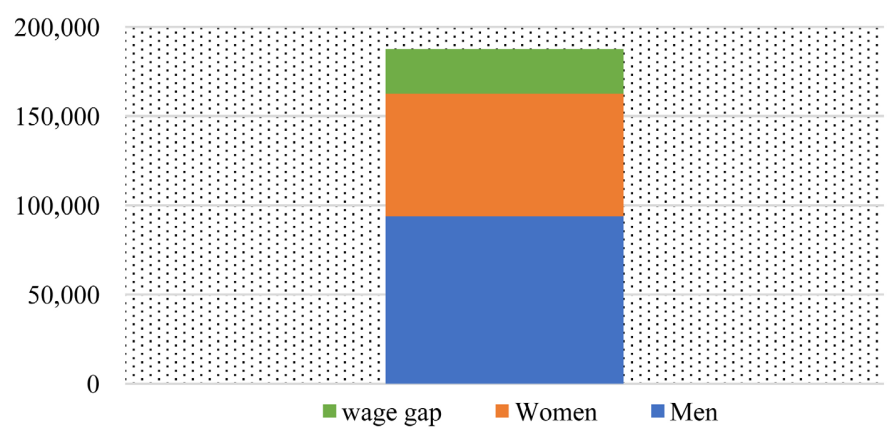

Figure 1. Salary distribution and wage gap (in CFA francs) by gender in Côte d'Ivoire (2016). Source: ENSESI 2016.

differentials between men and women. In the early 1970s, this was explained by both the human capital theory (Mincer \& Polachek, 1974) and Becker's (1971) discrimination theory.

According to Mincer and Polachek (1974), the pay gap between men and women is justified by the difference in individual characteristics. Women invest less in their human capital because they anticipate, first, the career interruptions they will be subject to throughout their working lives or the work stoppages they will take, and second, that their professional career will be shorter than that of a man because of their family responsibilities. However, the work of Oaxaca-Blinder (1973) combines these two theories. For these authors, the wage gap between men and women is in fact broken down, on the one hand, by differences in characteristics between the sexes and, on the other hand, by the discrimination to which women are subjected in the labour market. Furthermore, the wage gap is justified by the theory of human capital developed by Gary Becker (1964).

This theory is strongly dominant in neoclassical circles and is based on the hypothesis of the heterogeneity of human capital in the supply of labor, according to which: the level of qualification, which determines the productivity of the worker, is the main factor in setting the wage. Moreover, human capital, a determinant of wages, represents an investment on both the supply and demand sides of the labor market. Indeed, it allows workers (men and women) to increase their wages for the same amount of work. In addition, work experience is a stock of formal and informal human capital (practice and seniority). To this end, this theory considers work experience as a voluntary alternative to other learning processes (Lecourt, 2011). This presupposes the anticipation of opportunity costs in time and money which, according to Becker, implies a calculatory rationality of economic agents depending on financial constraints, individual capacities and socio-economic status (Lecourt, 2011). Between experience and training, women and men are not equal. Women, considered to have little professional and political experience, find it difficult to gain easy access to decision-making positions. Also, family constraints are the main obstacles for the majority of them to benefit from training. Consequently, this affects their competence, motivation and salary. In this theory developed by Becker (1962; 1993), 
wage differences reflect the investment in training made by individuals throughout their lives, and particularly during the initial education phase. This theory is situated in the framework of perfect competition: wages are directly linked to individual productivity, which in turn results from the acquisition of skills that can be valued on the labour market. Individuals, depending on their own characteristics, would decide on their investments in human capital by seeking to maximize the wages obtained throughout their career.

According to defenders of the human capital thesis (Mincer \& Polachek, 1974; Polachek, 1981; 2004), women's weaker integration into the labour market explains the gender wage gap. They are less developed in their earning activities, and they accumulate less work experience and skills in their profession. They also undergo less initial and continuous training, which would reduce their human capital and make them less productive. For these reasons, companies would not be willing to pay them the same wages as men or provide them with jobs that pay as well as men. However, gender wage differences cannot be explained by human capital alone. This is seen in the discriminatory wage difference, which cannot be explained. With the same qualifications and, therefore, the same human capital, women are simply paid less than men (Aisenbrey \& Brückner, 2008). It is in the same vein that the gender decompositions of wage differentials initiated by the work of Oaxaca-Blinder (1973) have become one of the favored avenues of study in this area. This method is based on the idea that there is a part explained by differences in productive capacities (level of education, professional experience, seniority in the job) and by differences in the structure of employment (sectors, size of firms, occupations), and another part resulting from a difference in pay for identical characteristics between men and women. Several studies have been conducted to explain the wage gap and most are based on a combination of these economic theories.

Another study was conducted in India on gender wage inequality in the agricultural sector. According to this study, the size of the village influences the gender wage gap. To this end, the study revealed that in large villages, the growth in women's wages relative to men's was significantly lower. In other words, gender wage inequality in India's agricultural sector widens as village size increases (Srivastava \& Sengupta, 2016).

However, The Civil Rights Act of 1964 ended legal discrimination against women in the labor market. While this reduced employment barriers, discrimination could still occur in several ways, such as women being less likely to be accepted in male-dominated occupations or less likely to be considered for promotion into managerial positions (Blau \& Kahn, 2017).

Previous studies have examined the effect of marriage and children on the wage gap. This allows us to see whether the gap is primarily explained by the lower earnings of married women relative to unmarried women, or the lower earnings of unmarried men relative to married men (or both). Then the literature reveals how children play a larger role in the gender income gap. In other 
words, children can contribute to lower earnings for women. Children are seen as important contributors to the wage gap (Iceland \& Redstone, 2020).

\subsection{Wage Gaps-Empirical Implications}

Many studies have been conducted to explore the history, magnitude, source, and underlying reasons for the wage gap. To provide clear explanations of the wage gap, a recent study was conducted in Turkey. According to this study, the wage gap between men and women in Turkey can be explained almost entirely by discrimination against women in the labor market. Through the Oaxaca decomposition method, this study reveals that $13 \%$ of the gap comes from observable gender differences and the remaining $87 \%$ is attributable to wage discrimination (Akhmedjonov, 2012). Furthermore, for more explanation on the gender wage gap, another study was conducted in China. In this paper, by the same decomposition method, education accounts for only $6 \%$ of the wage gap with a negative sign, indicating that education widens the wage gap between women and males. While in the unexplained part, education shows a positive effect and explains $23 \%$ of the discrimination. This is explained by the fact that women have a higher level of education than men, while they are paid particularly less on jobs. In addition to education, among all characteristics, occupation has the strongest power in the explained part. It explains $27 \%$ of the wage gap ( $\mathrm{Su} \&$ Heshmati, 2011). For these authors, occupation plays an important role in explaining the wage gap while education, instead of explaining the wage gap, contributes to gender discrimination in labor markets. In addition, a review of empirical studies on wage gaps was observed by public-private sectors. The public-private wage gap was found to decrease with the distribution of wages: large, positive gaps for the lowest paid workers and small, positive, or even negative gaps for the highest paid workers (Azam \& Prakash, 2015; Cai \& Liu, 2011; Christofides \& Michael, 2013; Depalo \& Giordano, 2011; Foley \& O’Callaghan, 2011; Mizala, Romaguera, \& Gallegos, 2011; Papapetrou, 2006; Poterba \& Rueben, 1994; Saha, Roy, \& Kar, 2014).

Otherwise, Śliwicki \& Ryczkowski (2014), show that women in Poland receive on average from $10.1 \%$ to $14.6 \%$ lower wages in comparison to men, because of potential discrimination. However, the level of virtual discrimination might be a little lower due to sociological, psychological and social factors that were not considered for the decomposition.

In South Korea, there appears to be explicit discrimination against women in general, with stronger discrimination against married women. Indeed, after accounting for differences in region, occupational category, duration of occupation, education, union membership, working for a large firm, industrial category of employment, and marital status, men received $26.2 \%$ more than women (the ratio is 0.792 ). The premium paid to married men raises the average wage of men relative to the average wage of women by $6.9 \%$ (the ratio is 0.935 ). Similarly, the marriage penalty for women lowers average women's wages relative to 
men's wages giving a ratio of 0.987 . In other words, men's average wages relative to women's wages are $1.3 \%$ higher due to the effect of the marriage penalty for women. There is also professional experience that would explain the pay gap between men and women. In this country, differences in experience and experience squared explain why men's average wages are $9.0 \%$ higher than women's wages (the ratio is 0.917 ). Males had 17.71 years of experience on average compared to 9.12 years for women. The difference (8.59) times the coefficient for experience (0.02) equals 0.172 . According to the decomposition, the combined effect on men's salary relative to women's is $0.172,2,0.086,5,0.086$. Thus, 0.086 is the difference in the $\ln \mathrm{W}$ of men relative to women. The antilogarithm is 1.09 . Hence, men earn 1.09 as much as women due to differences in experience (Monk-Turner \& Turner, 2000). In another article published in 2011, reveals that Reimers found, for men of Puerto Rico, discrimination may be responsible for $18 \%$ of the wage differential, on its part, for "other Hispanics", discrimination can cause up to $12 \%$ of the wage gap. For Mexicans, however, accounts of discrimination only amount to $6 \%$, the rest of the $34 \%$ wage gap is due to differences in characteristics such as education (Ospino, RoldánVasquez, \& Narváez, 2010).

In a report published by the Institute for Women's Policy Research (IWPR) in 2020, Income differences by gender, race and ethnicity, women of all major racial and ethnic groups earn less than men of the same group. They also earn less than white men. Hispanic workers have lower median weekly earnings than White, Black and Asian women workers. The median weekly earnings of Hispanic women in 2019 were $\$ 642$ per week of full-time work, only $56.0 \%$ of the median weekly earnings of non-Hispanic white men, but $85.9 \%$ of the median weekly earnings of Hispanic men (because Hispanic men also have low earnings).

Juhn \& McCue (2017) focused on the role of marriage and children in explaining the gender earnings gap across cohorts, and found that earnings gap attributable to marriage has declined over time, but the gap attributable to children has been more persistent, and the proportion of the gap associated with children increased. More specifically, using data from the 1968 to 2014 Current Population Surveys (CPS), they found that among full-time, year-round workers, at age 30 the earnings gap for those born in 1936-1945 was 0.54, and that marriage contributed 0.19 points to the gap and children another 0.10 . But for the cohort born in 1976-1985, the overall gender earnings gap had fallen to 0.14, with marriage and children each contributing 0.04 to the gap.

The literature and specialized theory point to a "rich" list of determinants that explain the wage differentials between men and women. These include socio-demographic and occupational characteristics such as age, experience, gender, marital status, education, job type, occupation, etc. In the classical theory of human capital, age has a positive effect on the remuneration of individuals up to a certain level. Indeed, in France, in a study published by the Di- 
rectorate for Research, Studies and Statistics DARES (2015), on average, across the whole of France, the gender wage gap was $-8.6 \%$ for employees under 30 years of age, $-18.5 \%$ for those aged 30 - 49 years and $-27.3 \%$ for employees aged 50 years or older. The increase in the wage gap with age can also be linked to women's working life cycle. From the beginning of their working careers, and despite a level of education comparable to or even higher than that of men, the wage gap is established to the disadvantage of women, in particular because of the choice of career paths that may lead to lower-paid professional opportunities. It increases up to the age of 35 , in connection with the arrival of motherhood, and consequently widens due to the lesser accumulation, on average, of professional experience.

In the literature review, research indicates that the gender earnings gap among full-time workers varies somewhat across groups, with a larger gap among whites (white women earn 78 percent of what white men did in 2019) and Asians (77 percent), than Hispanics (86 percent) and blacks (92 percent) (Institute for Women's Policy Research, 2020). These gaps likely vary due to a combination of factors, such as differences in human capital accumulation and discrimination (Snipp \& Cheung, 2016).

According to Elise Coudin et al. (2017), differences between women and men in terms of degree, age, experience, seniority in the company, socio-professional category, work share, sector of activity, region of employment and company size contribute 5.9 points to the average hourly wage gap (explained gap). Put another way, if these characteristics were valued among women as they are among men, the gender wage gap would be reduced to $5.9 \%$. Numerous studies show that, like developed countries, developing countries are also affected by wage discrimination. For example, in Guinea, Glick and Sahn (1997) find that differences in characteristics account for $45 \%$ of the male-female income differential in the case of the self-employed, which is reduced to $25 \%$ in the public sector. Also, Siphambe and Thokweng-bakwena (2001) argue that while in the Botswana public sector the bulk of the gross wage differential is explained by differences in characteristics between men and women and not by wage discrimination, in the private sector, female employees earn more than their male counterparts.

\section{Methodology and Empirical Results}

The decompositions of gender wage differentials undertaken by Oaxaca (1973) and Blinder (1973) provide a valuable methodological tool for the analysis of wage disparities. According to this methodology, gender wage differentials are first explained by differences in productive capacities and differences in the structure of employment, and then by discrimination.

\subsection{Methodology}

To measure and explain the gender wage gap, we use the Oaxaca-Blinder (1973) 
wage decomposition. This empirical method of Oaxaca (1973) and Blinder (1973) consists in controlling, in a sample of employees of both sexes or of different groups, for all the individual characteristics that give rise to differences in terms of pay: education, training, work experience, social origin, sector of activity, etc., so as to isolate a residual, inexplicable by these normal factors of pay inequality, which captures gender discrimination. In other words, the aim would be to assess the percentage of the average wage gap between men and women that can quantify this gender discrimination. The formulation of the analysis model is as follows:

$$
w_{g i}=\beta_{g 0}+\sum_{k=1}^{k} X_{i k} \beta_{g k}+U_{g i}
$$

$w_{g i}$ is the logarithm of the wage of an individual $i$ of $\operatorname{sex} g(\mathrm{~F}=$ woman; $\mathrm{H}=$ man) which is modelled by a linear function of the individual's characteristics $X_{i 1}, X_{i 2}, \cdots, X_{i k}$ (here: diploma, age, experience, seniority in the company, socio-professional category, work share, sector of activity, region of employment and company size) valued differently according to his or her sex, and an error term $U_{g i}$ which verifies $E\left(U_{g i} \mid X_{i}, g(i)=g\right)=0$ (conditional mean null).

The Oaxaca-Blinder (1973) decomposition estimates the wage equations for men and women separately:

$$
\bar{W}_{F}=\beta_{F 0}+\sum_{k=1}^{K} \bar{X}_{F k} \beta_{F k}
$$

And

$$
\bar{W}_{H}=\beta_{H 0}+\sum_{k=1}^{K} \bar{X}_{H k} \beta_{H k}
$$

The gap $\Delta_{0}$ between the logarithm of the average male wage $\left(\bar{W}_{H}\right)$ and the logarithm of average female wage $\left(\bar{W}_{F}\right)$ is then decomposed into the explained gap ( $\left.\Delta_{\text {explained }}\right)$ and an unexplained gap $\left(\Delta_{\text {unexplained }}\right)$.

$$
\begin{gathered}
\Delta_{0}=\bar{W}_{H}-\bar{W}_{F}=\left(\beta_{H 0}+\sum_{k=1}^{K} \bar{X}_{H k} \beta_{H k}\right)-\left(\beta_{F 0}+\sum_{k=1}^{K} \bar{X}_{F k} \beta_{F k}\right) \\
\Delta_{0}=\left(\sum_{k}\left(\bar{X}_{H k}-\bar{X}_{F k}\right) \beta_{H k}\right)+\left(\left(\beta_{H 0}-\beta_{F 0}\right)+\sum_{k} \bar{X}_{F k}\left(\beta_{H k}-\beta_{F k}\right)\right)
\end{gathered}
$$

With:

$\sum_{k}\left(\bar{X}_{H k}-\bar{X}_{F k}\right) \beta_{H k}$ the explained variation noted $\Delta_{\text {explained }}$

$\left(\beta_{H 0}-\beta_{F 0}\right)+\sum_{k} \bar{X}_{F k}\left(\beta_{H k}-\beta_{F k}\right)$ the unexplained variation noted $\Delta_{\text {unexplained }}$

$\bar{X}_{H k}$ for example, corresponds to the average of the characteristic $X_{K}$ on the group of men.

In practice, the coefficients involved in the decomposition are estimated by separated linear regressions for women and men. $\Delta_{\text {explained }}$ corresponds to the wage gap arising from the differences in characteristics between men and women: this is the gap that would remain if each characteristic were valued the same in both genders. Men are taken here as the reference population-in the absence of differences in the valuation of characteristics, women would be paid the same as men $\Delta_{\text {unexplained }}$ is the gap that results from differential valuations of these characteristics between men and women. 


\subsection{Databases}

In Côte d'Ivoire, the most recent data source that gathers information to quantify wage discrimination between men and women is the National Survey on the Situation of Employment and the Informal Sector (ENSESI, 2016). This is a survey conducted in 2016 among households and had 2 phases. In its first phase, the sample consisted of 44,003 individuals and it is this final phase that was selected for this study because it is more complete and more appropriate. From the point of view of our objectives, this source is the most appropriate for the object of our study. In our case study, we will use the final phasel because it is completed and more adapted to our study. The sample we have, after data reprocessing, includes 10,970 individuals who are employed or who receive income from their main job, of which 6982 are men and 3988 are women. It provides information on various individual characteristics.

The variable Inwage is the natural logarithm of reported monthly income, either as an amount or as an interval. It includes wages, salaries, and other cash or in-kind earnings from work. The variables selected to explain income are: age, age squared, gender, education, work experience, industry, employment setting, work hours, socio-professional category, employment sector, marital status and form of remuneration (see Table A1 in the Appendix for the different annotations).

\section{Results}

In this section, we report the descriptive statistics for the variables of interest and the wage estimates for men and women. Then, we present the results of the decomposition of the wage gap between men and women in the Ivory Coast labor market.

\subsection{Some Descriptive Statistics}

The descriptive statistics of the variables used for salaried individuals, in general and by gender, are summarized in Tables A2-A4 (see Appendix). We observe that the average age of employees and self-employed workers is about 37 years. At this age, most Ivorians in the labor market are in a couple and married$60.42 \%$ - civil marriage, customary marriage and/or religious marriage-Employees and the self-employed have an average primary education at $22.37 \%$, secondary education at $19.37 \%$, and higher education at $3.75 \%$. The vast majority $(54.51 \%)$ are uneducated. The human capital endowments show that male employees are more educated and professionally trained than females, both at secondary and higher levels. Indeed, $22.56 \%$ of male employees have secondary education, compared to $13.77 \%$ of female employees, and $4.63 \%$ of male employees have higher education, compared to $2.20 \%$ of female employees. It is also noticeable that after interrupting their primary or secondary education, many Ivorians start looking for work, thus abandoning their higher education. 
The breakdown by socio-professional category shows that non-agricultural laborers remain the most important group in the labor market overall, with $20.31 \%$ of the workforce. In this group, men are in the majority, with a proportion of $21.31 \%$ against $16.94 \%$ for women. Semi-skilled workers come second (20.17\%), with men dominating-20.69\% compared to $18.87 \%$ for women-followed by skilled workers (17.95\%), with men still dominating-19.16\% for men compared to $13.87 \%$ for women. Senior managers or engineers and similar are the last of the whole socio-professional category (2.98\%). Men are in the majority in this group with a proportion of $3.3 \%$ against $1.8 \%$ for women.

As regards institutional sectors, Ivorian employees are on average in the majority in the informal sector (94.63\%). Female employees are more numerous in this sector with a proportion of approximately $96.76 \%$, compared to $93.41 \%$ for men. In the formal sector, there are more male employees than female employees-6.4 percent men versus 3.2 percent women. The labor market in Côte d'Ivoire is also characterized by the phenomenon of rural exodus. Ivorian women employees are mostly found in urban areas (54.03\%). They leave the villages and come to the city where they hope to find more job opportunities. As for men, $53.04 \%$ live in rural areas where the conditions of access to employment are less restrictive.

\subsection{The Decomposition of the Wage Gap: Empirical Result}

The objective of our work is to distinguish, in the total wage gap between men and women, the part that is the consequence of a difference in characteristics (as we have seen in the presentation of the model, Oaxaca-Blinder), and the part that cannot be explained, which is therefore discriminatory.

Table A5 (see appendix) presents the results of the Oaxaca-Blinder decomposition of the wage differential by gender. They show that the estimated average monthly wage of men is higher than that of women. In fact, the coefficient of the estimated average log wage for men is 11.046 , while that of women is 10.658 , a wage gap of 0.3881 . In other words, the decomposition predicts an average wage gap of $38.81 \%$, that is, women earn on average $38.81 \%$ less than men. The decomposition of this gap shows that the explained share related to differences in individual characteristics is 0.10028 , or $25.84 \%$ ( 0.10028 out of 0.3880652$)$ of the total wage gap. The unexplained share associated with differences in returns to individual characteristics and attributed to wage discrimination is 0.287779 , or $74.16 \%(0.287779$ out of 0.3880652$)$ of the total gap. Given these results, there is every reason to believe that the gender wage gap is largely due to the unexplained part of Oaxaca-Blinder. Thus, our decomposition results support the hypothesis of discrimination against women in the Ivory Coast labor market.

Considering the decomposition of the different variables in Table A6 (see appendix), the greatest contributors to the wage gap between men and women are: age, which explains $32.37 \%$ ( 0.1256 out of 0.388 ) of the total wage difference, age squared $(-105.82 \%)$, the socio-professional category "senior manager" (3.55\%), 
then the form of pay $(29.89 \%)$.

Age plays an important role in salary formation. It explains $32.37 \%$ of the salary gap. It is often associated with professional experience: men have more experience than women because they usually work in their profession without interruption-about 12 years of experience against 8 years for women. The increase in the wage gap with age is also related to the working life cycle of women (Chamkhi, 2015). From the beginning of their professional career, at the same age, the wage gap is established to the disadvantage of women, due to their interruption of the professional activity, child rearing and family tasks, and reduce their occupation rate for this reason.

However, we observe that the square of the age contributes to reduce the average wage gap by $105.82 \%$. This variable reveal that beyond a certain age, at the optimum, the additional increase of one year contributes to the decrease of the gain (log wage), for both sexes (men and women). There is thus a catch-up effect of women's wages on men's. This means that this effect decreases the wage gap as the age of the two groups increases. We also note that there is a clear effect of human capital variables on wage differentiation. Indeed, the wage gap by education levels is negative $(-88.59 \%)$. This shows that better educated women receive on average a higher wage than men for the same characteristics. An additional year of education would therefore decrease the probability that a woman is discriminated against. In this case, it is the men who are disadvantaged.

As far as work experience is concerned, it explains about $4 \%$ ( 0.01521 out of 0.3880652 ) of the wage difference between men and women. Women have on average less experience than men, mainly because of more frequent career breaks. They have to acquire a longer experience on the labor market before entering the job market, which keeps a good part of them in a situation of unemployment and therefore of lack of income, inducing precariousness and vulnerability.

Secondly, the variable of the form of remuneration increases the male-female wage gap by $29.89 \%$. In other words, wage discrimination against women increases by $29.89 \%$ depending on the form of remuneration (fixed salary, paid by task or by commission or by profit etc.). Increasingly, in the Ivorian labor market, many women earn their income in the form of profit $-38.20 \%$ of men against $62.98 \%$ of women-(see Table A7 in the appendix).

Socio-professional category is also an observable element. In fact, the wage gap between the two sexes is $3.55 \%$ in favor of men among senior executives. It is $1.58 \%$ among non-agricultural workers, again in favor of men. On the other hand, among middle managers, the gap is $3.09 \%$, then $4.34 \%$ among skilled workers and $7.48 \%$ among semi-skilled workers, and finally $5.03 \%$ for agricultural laborers, but this time in favor of women. Furthermore, the difference in income between men and women according to age and socio-professional category is due to the fact that, in the Ivorian labor market, women are under-represented among managers and occupy low-paying positions. Also, they are 
generally too young and have difficulties to access highly qualified and better paid positions. Many women are in charge of unpaid family and childcare tasks, for example, and leave the labor market temporarily or reduce their workload. This works against them in terms of wages.

However, the average wage gap between men and women by sector of employment has a negative effect (i.e. $-16.80 \%$ ). In fact, the sector of employment tends to reduce the average wage gap by $16.80 \%$ depending on the production unit (public administration, parastatal company, farm, associative or cooperative company, etc.) in which the individuals carry out their activity. In this case, it is men who are marginalized. With regard to sector of activity, marital status and working hours, the average wage gap is reduced by $4.36 \%$ in the formal sector, $7.98 \%$ for single persons and $10.75 \%$ for women. As for the area of residence, the wage gap in urban areas is $88.56 \%$ in favor of men. In other words, a woman's move to the city reduces the probability that she will be discriminated against because the best opportunities and businesses are in urban areas. They therefore move from the villages to the city where they hope to find more job opportunities. Marital status (single), its explained share is 3\% (0.0030114 out of $0.1002859)$, or $0.77 \%$ ( 0.0030114 out of 0.3880652$)$ of the total gap. This gap is less pronounced in the formal contract, where it is $1 \%$ to the disadvantage of women.

\section{Conclusion}

The objective of this study is to measure the gender wage gap in the Ivory Coast labor market. The decomposition of the gender wage gap has made it possible to isolate a residual that cannot be explained by the traditional factors of pay inequality. This residual, attributed to wage discrimination between the two sexes, indicates the extent to which the principle of "equal pay for equal work" is not respected. Our results also show that women are more present in the informal sector where wages are low, while men hold senior positions in formal enterprises (private or public) where wages are high. This study highlights the different facets of the wage gap between men and women and shows that the wage gap exists in the Ivorian labor market. Moreover, the wage gap is a consequence of the structure of the labor market and is also linked to the different positions occupied by men and women in this market. In other words, the wage differentiation between men and women varies according to their job income, status and position. A limitation of this work is that the sample of the employed population was 10,907 individuals aged 15 years and over. For this purpose, the database of our work is based on a sample of 44,003 individuals and only 10,907 individuals are aged 15 years and over, and who declared their salary. Because the ENSESI database (2016) unfortunately contains a lot of missing data on some variables (dependent variable and explanatory variables). However, the cross-tabulation of several explanatory variables and the search for a good and robust model in the wage decomposition led to the reduction of the sample to 2531 observations. 
Another limitation is that certain determinants or factors such as firm size were not taken into account. This could be the subject of another study.

In view of the various results thus obtained, our study suggests an improvement in labor market policies and the promotion of women's employment in the various sectors of activity. Also, it will be necessary to promote the access of women to positions that offer high salaries or to highly qualified functions. This is why, at present, gender equality in sustainable human development is advocated and one of its fundamental objectives is to achieve the empowerment of women and girls. Thus, addressing the wage gap is considered a priority by international and national policymakers, both because it represents unacceptable discrimination from a human rights perspective and because it is harmful to the economy. Through our study, we suggest a number of economic policy measures such as:

Eliminate barriers that hinder women's access to the labor market in order to help them build a good professional career.

Creating productive and appropriate employment opportunities for women to access higher skilled and better paid jobs.

Correct the over-representation of men by giving women more opportunities in higher jobs. This can be achieved, for example, by directing women to networks of influential women who will give them the desire and motivation to advance.

Develop greater transparency in individual salary negotiations. Provide symmetrical and clear information that allows for a more open approach to individual salary negotiations and how individuals are compensated.

Create productive, women-friendly, and better-paying jobs in both rural and urban areas to prevent rural-urban migration and reduce the gender gap.

Fight against cultural practices that are unfavorable to girls' education. More generally, in developing countries, particularly in Africa, social and cultural gender norms confine women to the home. It is therefore necessary to set up a project seeking to change behaviors and social norms by raising women's awareness, as they participate in economic life.

Promote and sensitize women by organizing seminars on equal employment opportunity policy and on issues related to gender equality in political, economic and social decision-making.

To engage and encourage union representatives (male and female) in the promotion of equal pay.

\section{Conflicts of Interest}

The authors declare no conflicts of interest regarding the publication of this paper.

\section{References}

Aisenbrey, S., \& Brückner, H. (2008). Occupational Aspirations and the Gender Gap in 
Wages. European Sociological Review, 24, 633-649. https://doi.org/10.1093/esr/jcn024

Akhmedjonov, A. (2012). New Evidence on Pay Gap between Men and Women in Turkey. Economics Letters, 117, 32-34.

Azam, M., \& Prakash, N. (2015). A Distributional Analysis of Public-Private Wage Differential in India. Labour, 29, 394-414. https://doi.org/10.1111/labr.12068

BAD (2015). Profil genre pays: République de la Cote d'Ivoire. Groupe de la Banque Africaine de Développement.

Becker, G. S. (1962). Investment in Human Capital: A Theoretical Analysis. Journal of Political Economy, 70, 9-49. https://doi.org/10.1086/258724

Becker, G. S. (1964). Human Capital. A Theoretical and Empirical Analysis, with Special Reference to Education. University of Chicago Press.

Becker, G. S. (1971). The Economics of Discrimination. University of Chicago Press. https://doi.org/10.7208/chicago/9780226041049.001.0001

Becker, G. S. (1993). Human Capital: A Theoretical and Empirical Analysis with Special Reference to Education (3rd ed.). Chicago: University of Chicago Press. https://doi.org/10.7208/chicago/9780226041223.001.0001

Blau, F. D., \& Kahn, L. M. (2017). The Gender Wage Gap. Journal of Economic Literature, 55, 789-865. https://doi.org/10.1257/jel.20160995

Blinder, A. S. (1973). Wage Discrimination: Reduced Form and Structural Estimations. The Journal of Human Resources, 8, 436-455. https://doi.org/10.2307/144855

Cai, L. X., \& Liu, A. Y. C. (2011). Public-Private Sector Wage Gap in Australia: Variation along the Distribution. British Journal of Industrial Relations, 49, 362-390. https://doi.org/10.1111/j.1467-8543.2009.00773.x

Chamkhi, A. (2015). Les écarts de salaires femmes-hommes en 2010: Disparités territoriales par zones d'emploi. Direction de l'Animation de la Recherche, des Etudes et des Statistiques (DARES).

Christofides, L. N., \& Michael, M. (2013). Exploring the Public-Private Sector Wage Gap in European Countries. IZA Journal of European Labor Studies, 2, Article No. 15. https://doi.org/10.1186/2193-9012-2-15

Coudin, É., Maillard, S., \& Tô, M. (2017). Écarts salariaux entre les entreprises et au sein de l'entreprise: Femmes et hommes payés à la même enseigne? University College of London et Institute for Fiscal Studies.

DARES (2015). Les écarts de salaires femmes-hommes en 2010: Disparités territoriales par zones d'emploi.

Depalo, D., \& Giordano, R. (2011). The Public-Private Pay Gap: A Robust Quantile Approach. Bank of Italy Temi di Discussione (Working Paper) No. 824.

https://doi.org/10.2139/ssrn.1960983

Ekamena, S. N. (2014). Les écarts salariaux de genre au Cameroun. Revue Multidisciplinaire sur l'Emploi, le Syndicalisme et le Travail, 9, 124-146.

https://id.erudit.org/iderudit/1036261ar https://doi.org/10.7202/1036261ar

ENSESI (2016). Rapport descriptif sur la situation de l'emploi, tome 1. DGE.

ENSETE (2013). Rapport descriptif sur la situationn de l'emploi. INS, AGEPE.

Foley, P., \& O’Callaghan, F. (2011). Investigating the Public-Private Wage Gap in Ireland Using Data from the National Employment Survey 2007. Journal of the Statistical and Social Inquiry Society of Ireland, 39, 23-52. 
Glick, P., \& Sahn, D. E. (1997). Gender and Education Impacts on Employment and Earnings in West Africa: Evidence from Guinea. University of Chicago Press. https://doi.org/10.1086/452308

Hammouda, N. E., \& Souag, A. (2011). Y-a-t-il une discrimination salariale à l'encontre des migrants d'origine africaine en France? Les migrations Africaines: Droits et politiques, 2011, 99-119.

Iceland, J., \& Redstone, I. (2020). The Declining Earnings Gap between Young Women and Men in the United States, 1979-2018. Social Science Research, 92, Article ID: 102479. https://doi.org/10.1016/j.ssresearch.2020.102479

INS (2008). Etude sur le secteur informel à Abidjan: Caractéristiques des Unités de Productions Informelles à Abidjan, Enquête 1-2-3, phase 2.

Institute for Women's Policy Research (2020). The Gender Wage Gap: 2019 Earnings Differences by Race and Ethnicity.

Juhn, C., \& McCue, K. (2017). Specialization Then and Now: Marriage, Children, and the Gender Earnings Gap across Cohorts. Journal of Economic Perspectives, 31, 183-204. https://doi.org/10.1257/jep.31.1.183

Lecourt, A. J. (2011). Du Capital Humain aux Capabilités: une analyse des parcours de Validation des Acquis de l'Expérience. Thèse de Doctorat, Université Aix-Marseille II.

Lognon, J. L. (2013). Protection sociale et inclusion de l'informel: Une analyse des barrières à la création d'emplois décents dans l'économie informelle en Côte d'Ivoire. Economie Souterraine.

Meulders, D., Plasman, R., \& Rycx, F. (2005). Les inégalités salariales de genre: expliquer l'injustifiable ou justifier l'inexplicable. Reflets et Perspectives, 43, 95-107

Mincer, J., \& Polachek, S. (1974). Family Investment in Human Capital: Earnings of Women. Journal of Political Economic, 82, S76-S108. https://doi.org/10.1086/260293

Mizala, A., Romaguera, P., \& Gallegos, S. (2011). Public-Private Wage Gap in Latin America (1992-2007): A Matching Approach. Labour Economics, 18, S115-S131. https://doi.org/10.1016/j.labeco.2011.08.004

Monk-Turner, E., \& Turner, C. G. (2000). The Relative Pay of Men and Women in South Korea. Journal of Asian Economics, 11, 223-236. https://doi.org/10.1016/S1049-0078(00)00052-X

Oaxaca, R. (1973). Male-Female Wage Differentials in Urban Labour Markets. International Economic Review, 14, 693-709. https://doi.org/10.2307/2525981

Ospino, C. G., Roldán Vasquez, P., \& Narváez, N. B. (2010). Oaxaca-Blinder Wage Decomposition: Methods, Critiques and Applications. A Literature Review. Revista de Economía del Caribe, No. 5, 237-274.

Papapetrou, E. (2006). The Public-Private Sector Pay Differential in Greece. Public Finance Review, 34, 450-473. https://doi.org/10.1177/1091142106288998

Polachek, S. W. (1981). Occupational Self-Selection: A Human Capital Approach to Sex Differences in Occupational Structure. The Review of Economics and Statistics, 63, 60-69. https://doi.org/10.2307/1924218

Polachek, S. W. (2004). How the Human Capital Model Explains Why the Gender Wage Gap Narrowed. https://doi.org/10.2139/ssrn.527142

Ponthieux, D., \& Meurs, S. (2004). Les écarts de salaires entre les femmes et les hommes en Europe. Effet de structure ou discrimination? OFCE.

Poterba, J., \& Rueben, K. (1994). The Distribution of Public Sector Wage Premia: New Evidence Using Quantile Regression Methods. NBER Working Paper No. 4734. 
Saha, S., Roy, P., \& Kar, S. (2014). Public and Private Sector Jobs, Unreported Income and Consumption Gap in India: Evidence from Micro-Data. The North American Journal of Economics and Finance, 29, 285-300. https://doi.org/10.1016/j.najef.2014.07.002

Siphambe, H. K., \& Thokweng-Bakwena, M. (2001). The Wage Gap between Men and Women in Botswana's Formal Labour Market. Journal of African Economies, 10, 127-142.

Śliwicki, D., \& Ryczkowski, M. (2014). Gender Pay Gap in the Micro Level-Case of Poland. Metody Ilościowe w Badaniach Ekonomicznych, 15, 159-173.

Snipp, C. M., \& Cheung, S. Y. (2016). Changes in Racial and Gender Inequality since 1970. The Annals of the American Academy of Political and Social Science, 663, 80-98. https://doi.org/10.1177/0002716215596959

Srivastava, S. K., \& Sengupta, T. (2016). Growth Dynamics and Gender Wage Inequality in Indian Agricultural Sector: Study across Various Population Hierarchies of Villages. Theoretical Economics Letters, 6, 407-415. https://doi.org/10.4236/tel.2016.63045

$\mathrm{Su}, \mathrm{B}$. W., \& Heshmati, A. (2011). Analysis of Gender Wage Differential in China's Urban Labor Market. IZA Discussion Paper. https://doi.org/10.2139/ssrn.1981208 


\section{Appendix}

Table A1. Presentation and meanings of the variables.

\begin{tabular}{|c|c|}
\hline Variables & Signification \\
\hline lnsaliaire (dependent) & Logarithm of the wage from the main job \\
\hline Sexe & $\begin{array}{l}\text { Determines the gender of individuals } \\
\text { (gender: } 0 \text { male; gender } 1 \text { : female) }\end{array}$ \\
\hline Age & Age of respondents \\
\hline Education & $\begin{array}{c}\text { Educational level of individuals } \\
\text { (no education, primary, secondary and higher education) }\end{array}$ \\
\hline Expe & Work experience \\
\hline Etatciv & $\begin{array}{l}\text { Marital status (civil, religious, customary, } \\
\text { cohabiting, divorced, separated, widowed, never married) }\end{array}$ \\
\hline secteur 1 & $\begin{array}{l}\text { Sector of activity of agricultural or non-agricultural } \\
\text { employees (informal or formal sector) or institutional sector }\end{array}$ \\
\hline milieu 1 & Place of residence (urban or rural) or place of work \\
\hline Hortravail & Total number of hours spent at work \\
\hline CSP & $\begin{array}{c}\text { Socio-professional category (senior manager, middle manager, } \\
\text { semi-skilled worker, non-agricultural laborer, agricultural } \\
\text { laborer, domestic worker, other) }\end{array}$ \\
\hline Sectemploi & $\begin{array}{l}\text { The enterprise or unit in which the respondents (employees) } \\
\text { carry out their main activity (public administration, } \\
\text { public or parapublic enterprise, farm, } \\
\text { international organization, cooperative, household) }\end{array}$ \\
\hline Typecontrat & $\begin{array}{l}\text { Type of contract used in the main activity } \\
\text { (formal contract: fixed-term contract and } \\
\text { permanent contract, informal contract: verbal, no contract) }\end{array}$ \\
\hline Formre & $\begin{array}{l}\text { Form of remuneration: fixed salary (either monthly or } \\
\text { fortnightly), paid by task, paid by commission or by profit }\end{array}$ \\
\hline Aucunniv & Respondent has no education \\
\hline Prim & Respondent has a primary level of education \\
\hline Second & Respondent at secondary level \\
\hline Sup & Respondent has a higher level of education \\
\hline Sectform & Respondent works in the formal sector \\
\hline Sectinfor & Respondent works in the informal sector \\
\hline Cadresup & Individual is a senior manager \\
\hline Emplouvq & Respondent is a skilled worker \\
\hline Manoagr & The respondent is an agricultural laborer \\
\hline Urbain & The respondent lives in an urban area \\
\hline Rural & The respondent lives in an urban area \\
\hline
\end{tabular}

Source: Authors based on ENSESI 2016. The rural environment modality is the reference modality of the environment of residence. The informal sector modality is the institutional sector reference modality. 
K. S. B. Bediakon et al.

Table A2. Summary statistics of some variables.

\begin{tabular}{|c|c|c|c|c|c|}
\hline Presentation of some variables and annotation in the database & Obs & Mean & Std. Dev. & Min & $\operatorname{Max}$ \\
\hline Age & 10,907 & 37.89961 & 12.88326 & 15 & 99 \\
\hline \multicolumn{6}{|c|}{ Education } \\
\hline No education (none) & 10,907 & 0.5450628 & 0.497988 & 0 & 1 \\
\hline Primary (prim) & 10,907 & 0.2237095 & 0.4167487 & 0 & 1 \\
\hline Secondary (sec) & 10,907 & 0.1937288 & 0.395237 & 0 & 1 \\
\hline Superior (sup) & 10,907 & 0.0374989 & 0.1899895 & 0 & 1 \\
\hline \multicolumn{6}{|c|}{ Socio-professional category (CSP) } \\
\hline Upper management (cadreup) & 2718 & 0.0298013 & 0.1700701 & 0 & 1 \\
\hline middle management (cadremoy) & 2718 & 0.1225166 & 0.3279418 & 0 & 1 \\
\hline employee/skilledworker (emplouvq) & 2718 & 0.1795438 & 0.3838776 & 0 & 1 \\
\hline employee/semi-skilled worker (emplousq) & 2718 & 0.2027226 & 0.4021015 & 0 & 1 \\
\hline agricultural labourer (manoagr) & 2718 & 0.16078 & 0.3673955 & 0 & 1 \\
\hline non-agricultural labourer (mannagr) & 2718 & 0.2030905 & 0.4023734 & 0 & 1 \\
\hline Domestic (domest) & 2718 & 0.0592347 & 0.2361069 & 0 & 1 \\
\hline Other & 2718 & 0.0423105 & 0.2013337 & 0 & 1 \\
\hline \multicolumn{6}{|c|}{ Marital status (etatciv) } \\
\hline Marie & 10,907 & 0.6041991 & 0.4890444 & 0 & 1 \\
\hline Celibat & 10,907 & 0.3958009 & 0.4890444 & 0 & 1 \\
\hline \multicolumn{6}{|c|}{ Sector of activity (sector 1 ) } \\
\hline formal sector (sectform) & 10,907 & 0.053727 & 0.2254884 & 0 & 1 \\
\hline informal sector (sectinf) & 10,907 & 0.946273 & 0.2254884 & 0 & 1 \\
\hline
\end{tabular}

Source: Authors from ENSESI 2016.

Table A3. Descriptive statistics of variables by gender.

\begin{tabular}{|c|c|c|c|c|c|c|c|c|c|c|}
\hline \multirow{2}{*}{ Variables } & \multicolumn{5}{|c|}{ Man } & \multicolumn{5}{|c|}{ Woman } \\
\hline & Obs & Mean & Std. Dev. & Min & Max & Obs & Mean & Std. Dev. & Min & Max \\
\hline lnsalaire & 6950 & 10.85269 & 1.45623 & -2.4849 & 22.515 & 3957 & 10.1859 & 1.2987 & 0 & 22.51503 \\
\hline age & 6950 & 38.31151 & 12.7098 & 15 & 99 & 3957 & 37.1761 & 13.153 & 15 & 99 \\
\hline age2 & 6950 & 1629.288 & 1121.11 & 225 & 9801 & 3957 & 1555.02 & 1158.5 & 225 & 9801 \\
\hline expe & 6447 & 12.05382 & 11.1938 & 0 & 75 & 3565 & 8.88051 & 10.483 & 0 & 66 \\
\hline aucunniv & 6950 & 0.5011511 & 0.50003 & 0 & 1 & 3957 & 0.62219 & 0.4849 & 0 & 1 \\
\hline prim & 6950 & 0.2269065 & 0.41886 & 0 & 1 & 3957 & 0.21809 & 0.413 & 0 & 1 \\
\hline
\end{tabular}


Continued

\begin{tabular}{|c|c|c|c|c|c|c|c|c|c|c|}
\hline second & 6950 & 0.2256115 & 0.41801 & 0 & 1 & 3957 & 0.13773 & 0.3447 & 0 & 1 \\
\hline sup & 6950 & 0.0463309 & 0.21022 & 0 & 1 & 3957 & 0.02199 & 0.1467 & 0 & 1 \\
\hline sectform & 6950 & 0.0658993 & 0.24812 & 0 & 1 & 3957 & 0.03235 & 0.1769 & 0 & 1 \\
\hline sectinf & 6950 & 0.9341007 & 0.24812 & 0 & 1 & 3957 & 0.96765 & 0.1769 & 0 & 1 \\
\hline admin & 6950 & 0.0542446 & 0.22652 & 0 & 1 & 3957 & 0.0326 & 0.1776 & 0 & 1 \\
\hline entreppub & 6950 & 0.0130935 & 0.11368 & 0 & 1 & 3957 & 0.00809 & 0.0896 & 0 & 1 \\
\hline entprinag & 6950 & 0.3880576 & 0.48734 & 0 & 1 & 3957 & 0.6045 & 0.489 & 0 & 1 \\
\hline explagr & 6950 & 0.5332374 & 0.49893 & 0 & 1 & 3957 & 0.31741 & 0.4655 & 0 & 1 \\
\hline orginter & 6950 & 0.0014388 & 0.03791 & 0 & 1 & 3957 & 0.00051 & 0.0225 & 0 & 1 \\
\hline entpasso & 6950 & 0.003741 & 0.06105 & 0 & 1 & 3957 & 0.00126 & 0.0355 & 0 & 1 \\
\hline orgass & 6950 & 0.0028777 & 0.05357 & 0 & 1 & 3957 & 0.00025 & 0.0159 & 0 & 1 \\
\hline menag & 6950 & 0.0033094 & 0.05744 & 0 & 1 & 3957 & 0.03538 & 0.1848 & 0 & 1 \\
\hline
\end{tabular}

Source: Authors from ENSESI 2016. Number of observations: male $=6950$; female $=3957$.

Table A4. Continuation of the descriptive statistics of variables by gender.

\begin{tabular}{|c|c|c|c|c|c|c|c|c|c|c|}
\hline cadresup & 2098 & 0.0333651 & 0.17963 & 0 & 1 & 620 & 0.01774 & 0.1321 & 0 & 1 \\
\hline cadremoy & 2098 & 0.1210677 & 0.32628 & 0 & 1 & 620 & 0.12742 & 0.3337 & 0 & 1 \\
\hline emplouvq & 2098 & 0.1916111 & 0.39366 & 0 & 1 & 620 & 0.13871 & 0.3459 & 0 & 1 \\
\hline emplousq & 2098 & 0.2068637 & 0.40515 & 0 & 1 & 620 & 0.18871 & 0.3916 & 0 & 1 \\
\hline manoagr & 2098 & 0.1835081 & 0.38717 & 0 & 1 & 620 & 0.08387 & 0.2774 & 0 & 1 \\
\hline mannagr & 2098 & 0.2130601 & 0.40957 & 0 & 1 & 620 & 0.16935 & 0.3754 & 0 & 1 \\
\hline domest & 2098 & 0.0071497 & 0.08427 & 0 & 1 & 620 & 0.23548 & 0.4246 & 0 & 1 \\
\hline autres & 2098 & 0.0433746 & 0.20375 & 0 & 1 & 620 & 0.03871 & 0.1931 & 0 & 1 \\
\hline marie & 6950 & 0.6171223 & 0.48612 & 0 & 1 & 3957 & 0.5815 & 0.4934 & 0 & 1 \\
\hline celibat & 6950 & 0.3828777 & 0.48612 & 0 & 1 & 3957 & 0.4185 & 0.4934 & 0 & 1 \\
\hline urbain & 6950 & 0.4696403 & 0.49911 & 0 & 1 & 3957 & 0.54031 & 0.4984 & 0 & 1 \\
\hline rural & 6950 & 0.5303597 & 0.49911 & 0 & 1 & 3957 & 0.45969 & 0.4984 & 0 & 1 \\
\hline hortravail & 6950 & 2.153813 & 0.8087 & 1 & 3 & 3957 & 1.89436 & 0.8656 & 1 & 3 \\
\hline contrfor & 2098 & 0.3493804 & 0.47689 & 0 & 1 & 620 & 0.34032 & 0.4742 & 0 & 1 \\
\hline contrinf & 2098 & 0.4790276 & 0.49968 & 0 & 1 & 620 & 0.46129 & 0.4989 & 0 & 1 \\
\hline formre & 6950 & 3.470504 & 1.60942 & 1 & 6 & 3957 & 4.13874 & 1.4846 & 1 & 6 \\
\hline
\end{tabular}

Source: Authors from ENSESI 2016. Number of observations: male $=6950$; female $=3957$. 
Table A5. Oaxaca-Blinder decomposition of the gender wage differential.

\begin{tabular}{|c|c|c|c|c|c|c|}
\hline \multicolumn{3}{|c|}{ Blinder-Oaxaca decomposition } & \multicolumn{4}{|c|}{$\begin{array}{l}\text { Number of obs }=2531 \\
\text { Model }=\text { linear }\end{array}$} \\
\hline \multicolumn{3}{|c|}{ Group 1: sexe $=0$} & \multicolumn{4}{|c|}{$\mathrm{N}$ of obs $1=1945$} \\
\hline \multicolumn{3}{|c|}{ Group 2: sexe $=1$} & \multicolumn{4}{|c|}{$\mathrm{N}$ of obs $2=586$} \\
\hline Lnsalaire & \multicolumn{6}{|c|}{ Coef. Std. Err Z p > z [95\% Conf. Interval] } \\
\hline \multicolumn{7}{|l|}{ overall } \\
\hline Group_1 & $11.04652^{\star * *}$ & 0.0263929 & 418.54 & 0.000 & 10.99479 & 11.09825 \\
\hline Group_2 & $10.65845^{\star * \star}$ & 0.0545296 & 195.46 & 0.000 & 10.55158 & 10.76533 \\
\hline difference & $0.3880652^{\star * *}$ & 0.060581 & 6.41 & 0.000 & 0.2693286 & 0.5068019 \\
\hline explained & $0.1002859^{\star *}$ & 0.0421636 & 2.38 & 0.017 & 0.0176468 & 0.1829249 \\
\hline Unexplained & $0.2877794^{\star * *}$ & 0.0533005 & 5.4 & 0.000 & 0.1833123 & 0.3922464 \\
\hline
\end{tabular}

Source: Oaxaca-Blinder decomposition, using data from ENSESI, 2016. Significance of coefficients: ${ }^{\star *}$ at the $1 \%$ threshold, ${ }^{\star *}$ at the $5 \%$ threshold Group 1 (male) sex $=0$; Group 2 (female) sex $=1$ Number of employee observations: male $=1945$; female $=586$.

Table A6. Decomposition of variables wage gap.

\begin{tabular}{|c|c|c|c|}
\hline Decomposition of & Gap explained & Gap unexplained & Difference total \\
\hline variables wage gap & $0.1002859(25.84 \%)$ & $0.2877794(74.16 \%)$ & $0.3880652(100 \%)$ \\
\hline \multicolumn{4}{|c|}{ Decomposition detailed of the wage gap variables } \\
\hline age & $0.1255961^{\star * *}$ & 0.610796 & $\begin{array}{l}0.7363921 \\
(189.76 \%)\end{array}$ \\
\hline age 2 & $-0.068983^{\star *}$ & -0.341673 & $\begin{array}{c}-0.410656 \\
(-105.82 \%)\end{array}$ \\
\hline Expe & $0.01521^{\star \star}$ & -0.0327702 & $\begin{array}{c}-0.0175602 \\
(-4.53 \%)\end{array}$ \\
\hline Education & 0.0059616 & $-0.3497455^{\star * *}$ & $\begin{array}{c}-0.3437839 \\
(-88.59 \%)\end{array}$ \\
\hline Sectform & 0.0066731 & -0.0236087 & $\begin{array}{c}-0.0169356 \\
(-4.36 \%)\end{array}$ \\
\hline sectemploi & $0.0313509^{\star *}$ & -0.096565 & $\begin{array}{c}-0.0652141 \\
(-16.80 \%)\end{array}$ \\
\hline Cadresup & $0.009536^{*}$ & 0.004237 & $\begin{array}{c}0.013773 \\
(3.55 \%)\end{array}$ \\
\hline Cadremoy & -0.009056 & -0.0029542 & $\begin{array}{c}-0.0120102 \\
(-3.09 \%)\end{array}$ \\
\hline Emplouvq & $0.0163131^{\star *}$ & -0.0331387 & $\begin{array}{c}-0.0168256 \\
(-4.34 \%)\end{array}$ \\
\hline Emplousq & 0.0011667 & -0.0302075 & $\begin{array}{c}-0.0290408 \\
(-7.48 \%)\end{array}$ \\
\hline
\end{tabular}




\section{Continued}

\begin{tabular}{cccc}
\hline Manoagr & -0.014002 & -0.0054989 & -0.0195009 \\
& & & $-5.03 \%)$ \\
Mannagr & -0.0069731 & 0.0131009 & 0.0061278 \\
& & & $(1.58 \%)$ \\
Autres & 0.000496 & 0.0004451 & 0.0009411 \\
& & & $(0.24 \%)$ \\
Celibat & 0.0030114 & -0.0339758 & -0.0309644 \\
& & & $(-7.98 \%)$ \\
Urbain & -0.0124283 & $-0.3312399^{* *}$ & -0.3436682 \\
& & & $(-88.56 \%)$ \\
Hortravail & 0.0029283 & -0.0446459 & -0.0417176 \\
& & & $(-10.75 \%)$ \\
Contrfor & 0.0036413 & 0.0002574 & 0.0038987 \\
& & & $(1.00 \%)$ \\
Formre & $-0.0101562^{*}$ & $0.1261653^{*}$ & 0.1160091 \\
& & & $(29.89 \%)$ \\
_cons & & 0.858801 & 0.858801 \\
& & & $(221.30 \%)$ \\
\hline
\end{tabular}

Source: Oaxaca-Blinder decomposition from ENSESI 2016 data. Significance of coefficients at the threshold of: ${ }^{* \star} 1 \%,{ }^{*} 5 \%$ and ${ }^{\star} 10 \%$.

Table A7. Descriptive statistics of the form of wages by gender.

\begin{tabular}{cccccccc}
\hline \multirow{2}{*}{$\begin{array}{c}\text { How are you paid, or do you } \\
\text { get your income, in your job? }\end{array}$} & Freq. & Percent & Cum. & Freq. & Percent & Cum. \\
\cline { 3 - 7 } $\begin{array}{c}\text { fixed salary } \\
\text { (monthly, bi-weekly, weekly) }\end{array}$ & 1459 & 20.99 & 20.99 & 518 & 13.09 & 13.09 \\
By the day or by the hour & 199 & 2.86 & 23.86 & 50 & 1.26 & 14.35 \\
By the job & 2162 & 31.11 & 54.96 & 673 & 17.01 & 31.36 \\
Commission & 174 & 2.5 & 57.47 & 32 & 0.81 & 32.17 \\
Benefits & 2655 & 38.2 & 95.67 & 2492 & 62.98 & 95.15 \\
In kind (products, food, lodging) & 301 & 4.33 & 100 & 192 & 4.85 & 100 \\
Total & 6950 & 100 & & 3957 & 100 & \\
\hline
\end{tabular}

Source: Authors from ENSESI 2016. 